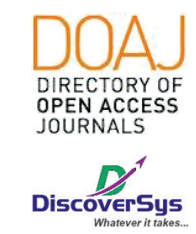

Published by DiscoverSys

\section{Gambaran karakteristik fraktur radius distal di RSUP Sanglah Tahun 2013-2017}

\author{
Irene Natalia Tantri, ${ }^{1}$ A. A. Gde Yuda Asmara, ${ }^{2}$ \\ Agus Roy Rusly Hariantana Hamid ${ }^{3}$
}

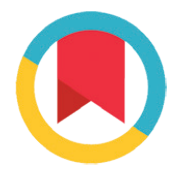

CrossMark

\section{ABSTRAK}

Latar Belakang: Fraktur radius distal merupakan fraktur yang paling sering ditemukan dalam bidang kegawatdaruratan ortopedi yang melibatkan ektremitas atas. Fraktur ini dapat terjadi disetiap kalangan usia mulai dari anak-anak, remaja hingga lansia. Terjadi peningkatan angka kejadian fraktur radius distal beberapa tahun belakangan ini, akan tetapi penelitian mengenai karakteristik fraktur radius distal, khususnya di Bali, masih jarang dilakukan.

Metode: Penelitian ini merupakan penelitian deskriptif-retrospektif yang bertujuan untuk mengetahui gambaran karakteristik fraktur radius distal di RSUP Sanglah, Denpasar, Bali. Pengumpulan data menggunakan teknik total sampling dengan menggunakan data sekunder berupa catatan medik pasien. Sampel penelitian adalah semua pasien yang terdiagnosa fraktur radius distal di RSUP Sanglah pada tahun 2013-2017 dengan kriteria eksklusi pasien dengan data tidak lengkap.
Hasil: Pada penelitian ini, diperoleh 677 kasus fraktur radius distal dimana sebagian besar adalah laki-laki yaitu 434 kasus $(64,1 \%)$ dengan perbandingan rasio laki-laki dan perempuan 1,8:1. Kasus terbanyak terdapat pada rentang usia 20- 29 tahun dengan total 147 kasus (21,7\%). Penyebab fraktur radius distal terbanyak adalah kecelakaan lalu lintas yaitu 322 kasus (47,6\%). Keluhan yang paling banyak menyertai fraktur radius distal adalah fraktur anggota ekstremitas atas selain radius distal yaitu sebesar 333 kasus (49,2\%). Berdasarkan lama rawat inap pasien di rumah sakit didapatkan waktu rawat inap terbanyak adalah kurang dari 5 hari yaitu pada 569 kasus (84\%).

Kesimpulan: Fraktur radius distal sebagian besar terjadi pada lakilaki pada usia 20-29 tahun dengan penyebab fraktur terbanyak akibat kecelakaan lalu lintas dan lama rawat inap kurang dari 5 hari.

Kata Kunci: Karakteristik, fraktur, radius distal

Cite This Article: Tantri, I.N., Asmara, A.A.G.Y., Hamid, A.R.R.H. 2019. Gambaran karakteristik fraktur radius distal di RSUP Sanglah Tahun 20132017. Intisari Sains Medis 10(3): 468-472. D0I: 10.15562/ism.v10i3.416

\title{
ABSTRACT
}

Background: Radius distal fracture is the most common fracture seen in emergency department which involves the upper extremity. Radius distal fracture can occur in any age, ranging from children, teenager until elderly patients. There is an increasing trend of radius distal fracture. However, the research on radius distal fracture characteristic, especially in Bali, is still limited.

Method: This study was a descriptive-retrospective study which aims to find out the characteristic of radius distal fracture at Sanglah General Hospital, Denpasar, Bali. For data collection, we used total sampling technique using secondary data from patients' medical records. The study sample was all patient diagnosed with radius distal fractures between the year 2013-2017 with incomplete medical record as the exclusion criteria.
Result: This study obtained 677 radius distal fracture samples. Most of the patients were male [434 cases $(64,1 \%)]$ with the most common age range was between $20-29$ years old [ 147 cases $(21,7 \%)]$. The most common etiology of radius distal fracture was traffic accident [322 cases $(47,6 \%)]$. Fracture of the other upper extremity parts, in addition to radius distal, was the most common complaints accompanying radius distal fractures [333 cases $(49,2 \%$ ]. Based on the length of stay, $84 \%$ patients were hospitalized less than 5 days.

Conclusion: Distal radial fracture was commonly seen in men with the age range between $20-29$ years old. Traffic accident was the most common cause of distal radial fracture with the average length of stay less than 5 days.
1Program Studi Sarjana Kedokteran dan Profesi Dokter Fakultas Kedokteran Universitas Udayana, Bali

${ }^{2}$ Bagian Orthopaedi dan Traumatologi RSUP Sanglah Denpasar, Bali

${ }^{3}$ Bagian Bedah Plastik RSUP Sanglah Denpasar, Bali

\footnotetext{
${ }^{*}$ Correspondence to:
}

Diterima: 20-02-2019

Disetujui: 20-04-2019

Diterbitkan: 01-12-2019

Keyword: Characteristic, radius distal, fracture.

Cite Pasal Ini: Tantri, I.N., Asmara, A.A.G.Y., Hamid, A.R.R.H. 2019. Gambaran karakteristik fraktur radius distal di RSUP Sanglah Tahun 20132017. Intisari Sains Medis 10(3): 468-472. D0I: 10.15562/ism.v10i3.416

\section{PENDAHULUAN}

Fraktur radius distal merupakan fraktur yang paling sering ditemukan dalam bidang kegawatdaruratan ortopedik yang melibatkan ektremitas atas. Fraktur ini dapat terjadi disetiap kalangan usia mulai dari anak-anak, remaja hingga lansia. Kalangan usia yang beresiko tinggi untuk mengalami fraktur radius distal adalah dewasa muda dan orang tua. Pada dewasa muda, fraktur disebabkan oleh 
trauma akibat energi tinggi yang berhubungan dengan kegiatan olahraga. Sedangkan pada orang tua, fraktur lebih banyak disebabkan oleh trauma akibat energi rendah dan osteoporosis. Penyebab dari fraktur radius distal disebabkan oleh berbagai macam faktor seperti usia, pola hidup, pola makan dan aktivitas sehari-hari

Jumlah kasus fraktur radius distal merupakan seperenam dari semua patah tulang dengan lebih dari 640.000 kasus yang terdata pada tahun 2001 hanya di Amerika Serikat. ${ }^{1}$ Di Swedia, angka kejadian fraktur radius distal adalah 24 per 10.000 orang/tahun. Dimana rasio antara perempuan dan laki-laki adalah 3:1. Peningkatan insiden fraktur radius distal sebanding dengan peningkatan usia. Kejadian fraktur radius distal di bawah usia 50 tahun yaitu sekitar 9 per 10.000 orang/tahun tanpa memandang jenis kelamin. Pada wanita, insiden fraktur meningkat tajam dari usia diatas 50 tahun dan meningkat dua kali lipat dengan setiap interval usia 10 tahun sampai usia 70 tahun dan mencapai puncaknya setelah usia 90 tahun yaitu 144 per 10.000 orang/tahun. ${ }^{2}$

Penatalaksanaan fraktur radius distal membutuhkan waktu yang cukup lama. Keberhasilan penatalaksanaan fraktur juga membutuhkan kontribusi pasien dalam menjalani fisioterapi. Pada umumnya penatalaksanaan fraktur dilakukan secara medis baik dengan tindakan operatif maupun non-operatif. Penanganan awal pada pasien fraktur juga harus dilakukan dengan cepat untuk mencegah komplikasi awal fraktur yaitu syok yang bisa berakibat fatal dalam beberapa jam setelah cedera.

Mengingat angka insiden yang tinggi, perkembangan tatalaksana fraktur dan sedikitnya penelitian yang ada mengenai karakteristik fraktur radius distal, maka peneliti tertarik untuk meneliti gambaran karakteristik penderita fraktur radius distal di RSUP Sanglah. Karakteristik yang diteliti antara lain usia, jenis kelamin, keluhan penyerta, penyebab fraktur, dan lama inap.

\section{METODE}

Jenis penelitian ini adalah deskriptif-retrospektif dengan menggunakan data sekunder berupa rekam medis pasien. Penelitian dilakukan di RSUP Sanglah Denpasar dari bulan Maret sampai Oktober tahun 2018. Teknik yang digunakan dalam pengumpulan sampel pada penelitian ini adalah total sampling, dimana sampel pada penelitian ini adalah seluruh pasien dengan fraktur radius distal yang tercatat rekam medisnya secara lengkap dan dirawat di RSUP Sanglah.

Adapun kriteria inklusi pada penelitian ini yaitu pasien fraktur radius distal yang dirawat di RSUP Sanglah periode 1 Januari 2013 hingga 31 Desember
2017 dengan data rekam medis lengkap yang mana mencakup usia, jenis kelamin, penyebab, keluhan penyerta dan lama inap. Sedangkan kriteria eksklusi berupa data rekam medis yang tidak lengkap dan tidak mencantumkan usia, jenis kelamin, penyebab, keluhan penyerta dan lama inap pasien. Seluruh data yang terkumpul kemudian dilakukan analisis dan ditampilkan dalam bentuk tabel serta narasi.

Penelitian ini sudah mendapatkan surat layak etik dari Komisi Etik Penelitian Fakultas Kedokteran Universitas Udayana/ Rumah Sakit Umum Pusat Sanglah, Denpasar.

\section{HASIL}

Jumlah sampel yang didapat adalah 677 sampel. Dari 677 sampel yang terdiagnosa fraktur radius distal di RSUP Sanglah pada periode 2013-2017 dengan usia termuda adalah 1 tahun dan usia tertua adalah 92 tahun. Frekuensi kasus pasien fraktur radius distal terbanyak terdapat pada rentang usia 20-29 tahun sebanyak 147 kasus $(21,7 \%)$ kemudian diikuti dengan rentang usia 10-19 tahun 145 kasus (21,4\%), rentang usia 30-39 tahun dengan 100 kasus (14,8\%), rentang usia 50-59 tahun 93 kasus (13,7\%), rentang usia 40-49 tahun dengan 89 kasus $(13,1 \%)$, dan jumlah terendah pada pada rentang usia $\geq 80$ tahun dengan 10 kasus $(1,5 \%)$. Berdasarkan karakteristik jenis kelamin, sebanyak $434(64,1 \%)$ pasien laki-laki mengalami fraktur radius distal dan 243 pasien sisanya adalah perempuan.

Fraktur radius distal sebagian besar disebabkan oleh kecelakaan lalu lintas (sebagai pengendara) yaitu sebanyak 322 kasus (47,6\%), diikuti oleh jatuh dari tempat tinggi dengan 52 kasus (7,7\%), jatuh dari ketinggian yang sama 116 kasus (51\%), terpeleset dan tersandung 51 kasus (7,5\%), loncat atau didorong dari tempat tinggi 42 kasus (6.2\%), kecelakaan lalu lintas (sebagai penumpang) 38 kasus (5,6\%), kecelakaan akibat berkendara dengan sepeda dan kontak dengan benda tumpul masing masing 13 kasus (1,9\%). Penyebab yang paling sedikit adalah terjepit diantara dua benda sebanyak satu kasus $(0,1 \%)$.

Keluhan yang paling banyak menyertai fraktur radius distal adalah fraktur anggota ekstremitas atas selain radius distal dengan total 333 kasus $(49,2 \%)$. Fraktur ekstremitas atas yang paling sering menyertai keluhan utama adalah fraktur pada klavikula, radius proksimal dan ulna. Selain fraktur ekstremitas atas, keluhan penyerta lain adalah cedera otak (cedera superfisial dan perdarahan intrakranial seperti perdarahan subdura, perdarahan subaraknoid, kerusakan otak local dan difus) dengan 86 kasus (12,7\%), fraktur 
Tabel 1 Gambaran Karakteristik Fraktur Radius Distal berdasarkan Usia di RSUP Sanglah tahun 2013-2017

\begin{tabular}{lcc}
\hline Usia (tahun) & Jumlah & $\begin{array}{c}\text { Persentase } \\
\text { (\%) }\end{array}$ \\
\hline$<10$ & 21 & $3,1 \%$ \\
$10-19$ & 145 & $21,4 \%$ \\
$20-29$ & 147 & $21,7 \%$ \\
$30-39$ & 100 & $14,8 \%$ \\
$40-49$ & 89 & $13,1 \%$ \\
$50-59$ & 93 & $13,7 \%$ \\
$60-69$ & 53 & $7,8 \%$ \\
$70-79$ & 19 & $2,8 \%$ \\
$\geq 80$ & 10 & $1,5 \%$ \\
\hline
\end{tabular}

Tabel 2 Gambaran Karakteristik Fraktur Radius Distal berdasarkan Jenis Kelamin di RSUP Sanglah tahun 2013-2017

\begin{tabular}{lcc}
\hline Jenis Kelamin & Jumlah & Persentase (\%) \\
\hline Laki-Laki & 434 & $64,1 \%$ \\
Perempuan & 243 & $35,9 \%$ \\
\hline
\end{tabular}

Tabel 3 Gambaran Karakteristik Penyebab Fraktur Radius Distal di RSUP Sanglah pada tahun 2013-2017

\begin{tabular}{lcc}
\hline Variabel Penyebab & Jumlah & Persentase (\%) \\
\hline Kecelakaan Lalu Lintas & 322 & $47,6 \%$ \\
Jatuh pada ketinggian yang sama & 116 & $17,1 \%$ \\
Terpeleset dan tersandung & 51 & $7,5 \%$ \\
Loncat, didorong dari tempat tinggi & 42 & $6.2 \%$ \\
Jatuh dari tempat tinggi & 52 & $7,7 \%$ \\
Kecelakaan saat berkendara dengan sepeda & 13 & $1,9 \%$ \\
Trauma pejalan kaki & 8 & $1,2 \%$ \\
Passenger collision injury & 38 & $5,6 \%$ \\
Kontak dengan benda tumpul & 13 & $1,9 \%$ \\
Kontak dengan benda tajam & 4 & $0,6 \%$ \\
Overexertion, strenuous, atau repetitive movement & 7 & $1,0 \%$ \\
Kekerasan & 4 & $0,6 \%$ \\
Caught, crushed, jammed, or pinched in or between & 1 & $0,1 \%$ \\
object & & \\
Terkena benda yang dilempar atau dijatuhkan & 2 & $0,3 \%$ \\
Ledakan dan benda panas & 2 & $0,3 \%$ \\
Kontak dengan mesin & 2 & $0,3 \%$ \\
\hline
\end{tabular}

ekstremitas bawah (fraktur tulang pinggul, tulang belakang bagian bawah, fraktur tibia dan fibula, fraktur femur) dengan 56 kasus (8,3\%), gangguan metabolic (hiponatremia, hipokalemia, kadar serum enzim abnormal) dengan 33 kasus (4,9\%), dan fraktur tulang kepala (termasuk tulang wajah seperti maksilla dan mandibulla) dengan 32 kasus
$(4,7 \%)$. Keluhan penyerta dengan jumlah paling sedikit adalah gangguan pada jaringan kulit dan subkutan dengan 2 kasus (0,\%).

Karakteristik pasien berdasarkan lama rawat inap di rumah sakit adalah waktu rawat inap paling banyak yaitu kurang dari 5 hari di rumah sakit dengan 569 kasus (84\%), diikuti dengan lama rawat inap 5-10 hari dengan 56 kasus (8,3\%), lama rawat inap 11-15 hari dengan 18 kasus (2,7\%), lama inap 16-20 hari dengan 11 kasus (1,6\%) dan paling sedikit pada rentang waktu lama rawat inap lebih dari 20 hari dengan 23 kasus $(3,4 \%)$.

\section{PEMBAHASAN}

Pada penelitian ini didapatkan rentang usia terbanyak pasien yang terdiagnosa fraktur radius distal adalah usia 20-29 tahun, kemudian diikuti dengan rentang usia 10-19 tahun. Rentang usia ini adalah masa remaja dimana remaja awal pada usia 12 16 tahun dan remaja akhir 17-25 tahun. Sehingga dapat disimpulkan bahwa semakin bertambah usia maka semakin sedikit jumlah kasus fraktur dimana setelah usia 50-59 tahun, jumlah kejadian fraktur lebih sedikit dibandingkan ketika masa puncak yaitu pada usia 10-19 tahun dan 20-29 tahun. Hal ini sesuai dengan penelitian yang dilakukan oleh Nellans $\mathrm{dkk}^{1}$ dimana frekuensi fraktur radius distal menurun pada usia 50 tahun keatas. Frekuensi kasus pada usia 10-19 tahun lebih tinggi dibandingkan $<10$ tahun karena pada saat pubertas terjadi pemisahan antara pertumbuhan tulang dan mineralisasi yang diduga mengakibatkan fragilitas tulang. Ketika tulang memanjang, kandungan mineral dalam tulang menurun akibat proses mineralisasi tulang tidak dapat mengikuti penambahan besar dari perkembangan tulang baru. Hal ini menyebabkan tulang menjadi rentan terhadap fraktur. ${ }^{1}$ Pada penelitian yang dilakukan Sahala dkk, ${ }^{3}$ ditemukan hasil yang serupa yaitu dari 30 kasus, kasus terbanyak terdapat pada rentang usia 20-29 tahun yaitu 11 kasus (36,66\%), diikuti dengan rentang usia 30-39 tahun dengan 6 kasus (20\%), usia $<20$ tahun dan usia 40 - 49 tahun masing -masing dengan jumlah 5 kasus $(16,67 \%)$ dan $>50$ tahun dengan 3 kasus (10\%).

Pada penelitian ini, didapatkan bahwa sebagian besar kasus adalah laki-laki dimana rasio antara laki-laki dan perempuan yang mengalami fraktur radius distal adalah 1,8:1. Hal ini serupa dengan penelitian yang dilakukan oleh Koo $\mathrm{dkk}^{4}$ yang menyatakan bahwa ratio jenis kelamin adalah 1,3:1 dengan laki-laki lebih banyak mengalami fraktur radius distal dibandingkan perempuan pada kasus kecelakaan lalu lintas. Penelitian yang dilakukan oleh Harahap dkk ${ }^{5}$ di RSUP Haji Adam Malik 
Tabel 4 Gambaran Karakteristik Keluhan Penyerta Fraktur Radius Distal di RSUP Sanglah tahun 2013-2017

\begin{tabular}{lcc}
\hline Penyebab & Jumlah & $\begin{array}{c}\text { Persentase } \\
\text { (\%) }\end{array}$ \\
\hline Fraktur ekstremitas atas & 333 & $49,2 \%$ \\
Fraktur ekstremitas bawah & 56 & $8,3 \%$ \\
Cedera otak & 86 & $12,7 \%$ \\
Anemia & 11 & $1,6 \%$ \\
Acute Post-hemorrhage & 13 & $1,9 \%$ \\
Dislokasi sendi & 26 & $3,8 \%$ \\
Cedera pada ligament, tendon, dan otot & 9 & $1,3 \%$ \\
Gangguan sistem saraf & 6 & $0,9 \%$ \\
Gangguan metabolic & 33 & $4,9 \%$ \\
Fraktur tulang kepala & 32 & $4,7 \%$ \\
Gangguan dan cedera pada organ sirkulasi & 12 & $1,8 \%$ \\
Gangguan dan cedera pada organ respirasi & 13 & $1,9 \%$ \\
Gangguan pendengaran dan keseimbangan & 3 & $0,4 \%$ \\
Gangguan dan cedera pada organ penglihatan & 9 & $1,3 \%$ \\
Kerusakan jaringan kulit dan subkutan & 2 & $0,3 \%$ \\
Gangguan dan cedera pada organ digestive dan abdomen & 20 & $3,0 \%$ \\
Gangguan dan cedera pada organ Genitourinary & 4 & $0,6 \%$ \\
Gejala umum & 6 & $0,9 \%$ \\
Gangguan degenerative tulang & 3 & $0,4 \%$ \\
\hline
\end{tabular}

Tabel 5 Gambaran Karakteristik Lama Inap Fraktur Radius Distal di RSUP Sanglah tahun 2013-2017

\begin{tabular}{lcc}
\hline Waktu Lama Inap (hari) & Jumlah & Persentase (\%) \\
\hline$<5$ & 569 & $84 \%$ \\
$5-10$ & 56 & $8,3 \%$ \\
$11-15$ & 18 & $2,7 \%$ \\
$16-20$ & 11 & $1,6 \%$ \\
$>20$ & 23 & $3,4 \%$ \\
\hline
\end{tabular}

Medan juga mendapatkan hasil yang serupa dengan pasien berjenis kelamin laki-laki sebanyak 38 kasus $(56,7 \%)$ dan sisanya berjenis kelamin wanita sebanyak 29 kasus $(43,2 \%)$ orang.

Pada penelitian ini, didapatkan penyebab terbanyak fraktur radius distal adalah kecelakaan lalu lintas (sebagai pengendara). Hasil penelitian ini sejalan dengan hasil penelitian yang dilakukan Harahap $\mathrm{dkk}^{5}$ di RSUP Haji Adam Malik Medan dimana fraktur terbanyak disebabkan oleh kecelakaan atau tekanan sebanyak 57 (85,7\%). Hasil yang sama didapatkan oleh Sahala $\mathrm{dkk}^{3}$ dimana fraktur radius distal paling banyak disebabkan oleh kecelakaan lalu lintas 22 kasus $(73,33 \%)$ dan diikuti oleh kecelakaan kerja 5 kasus $(16,67 \%)$.
Keluhan yang paling banyak menyertai fraktur radius distal pada penelitian ini adalah fraktur anggota ekstremitas atas selain radius distal yaitu fraktur pada klavikula, humerus, radius proksimal, ulna dan tulang jari. Selain itu, pasien dengan fraktur radius distal, juga memiliki keluhan penyerta berupa cedera otak, fraktur ekstremitas bawah, gangguan metabolik dan fraktur tulang kepala. Hasil ini serupa dengan studi yang dilakukan Bengner $\mathrm{dkk}^{6}$ dimana $45 \%$ pasien dengan fraktur radius distal memiliki cedera tambahan yang terbanyak berupa fraktur pada proksimal humerus, dan diikuti dengan fraktur panggul. Namun pada penelitian yang dilakukan Flamarion $\mathrm{dkk}^{7}$ didapatkan bahwa pasien yang mengalami kecelakaan lalu lintas mengalami fraktur ekstremitas bawah sebagai fraktur terbanyak $(22,6 \%)$ diikuti dengan fraktur ekstremitas atas $(8,9 \%)$, trauma pada thoraks $(6,85 \%)$ dan trauma otak $(6,17 \%)$.

Karakteristik lama rawat inap pasien pada penelitian ini didapatkan paling banyak waktu rawat inap kurang dari 5 hari. Hasil ini serupa dengan penelitian analisa deskriptif yang dilakukan Lolan ${ }^{8}$ di RS Panti Wilasa Dr. Cipto Semarang dimana lama rawat inap $\leq 3$ hari lebih banyak dibandingkan lama rawat inap $>3$ hari.

\section{SIMPULAN}

Dapat disimpulkan bahwa fraktur radius distal lebih banyak terjadi pada rentang usia 20-29 tahun dimana sebagian besar kasus berjenis kelamin laki-laki dengan rasio perbandingan laki-laki dan perempuan adalah 1,8:1. Penyebab tersering fraktur radius distal adalah kecelakaan lalu lintas. Fraktur radius distal paling banyak disertai dengan fraktur ekstremitas atas selain radius distal sebagai keluhan penyerta. Pasien dengan fraktur radius distal paling banyak dirawat selama kurang dari 5 hari.

\section{KONFLIK KEPENTINGAN}

Penulis menyatakan tidak memiliki konflik kepentingan terkait publikasi dari penelitian ini.

\section{PENDANAAN}

Penelitian ini tidak mendapatkan pendanaan oleh pemerintah ataupun lembaga swasta lainnya.

\section{ETIKA DALAM PENELITIAN}

Penelitian ini telah mendapatkan persetujuan dari Komite Etik, Fakultas Kedokteran Universitas 
Udayana/RSUP Sanglah Denpasar dengan nomor referensi 223/UN14.2/KEP/2018.

\section{KONTRIBUSI PENULIS}

Irene Natalia Tantri, A. A. Gde Yuda Asmara, Agus Roy Rusly Hariantana Hamid berkontribusi terhadap desain dan implementasi penelitian, analisa data hingga penulisan manuskrip.

\section{DAFTAR PUSTAKA}

1. Nellans K, Kowalski E, Chung K. The Epidemiology of Radius distal Fractures. Hand Clinics. 2012:28(2), pp.113-125.

2. Edi B, Manjas M, Riza A, Erkadius. Perbandingan Fungsi Ekstremitas Atas pada Fraktur Metafise Radius distal Intraartikuler Usia Muda Antara Tindakan Operatif Dan Non Operatif dengan Penilaian Klins Quickdash Score. 2014. Volume 3. Edisi 1.

3. Hutagalung S.M. Perbandingan Hasil Penanganan Fraktur Colles Tertutup Dengan Metoda Modifikasi Bohler, SDFDU dan FSPFDU. 2003:pp.17-18
4. Koo KOT, Tan DMK, Chong AKS. Radius distal Fractures: An Epidemiological Review. Spring Meeting of British Society for Surgery of the Hand. Manchester. 2010133:14-23.

5. Harahap Mhd, Windi S. Gambaran Penderita Radius Distal Fraktur di RSUP H. Adam Malik Periode 1 Januari 2012-31 Desember 2013. 2015. Diunduh dari : repository. usu.ac.id/handle/123456789/47731

6. Bengnér $U$, Johnell $O$. Increasing incidence of forearm fractures: A comparison of epidemiologic patterns 25 years apart. Acta Orthopaedica Scandinavica, 1985:56(2), pp.158-160.

7. Batista F, Silveira L, Castillo J, Pontes J, Villalobos L. Epidemiological profile of extremity fractures in victims of motorcycle accidents. Acta Ortopédica Brasileira, 2015:23(1), pp.43-46.

8. Lolan R. Analisa Deskriptif Variasi Kasus Fraktur di Bangsal Beta RS Panti Wilasa Dr.Cipto Semarang Triwulan 1 Tahun 2016. 2016. Diunduh dari: http://eprints.dinus. ac.id/1963

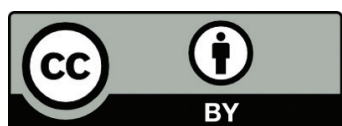

This work is licensed under a Creative Commons Attribution 